\title{
Mer blodpropp med nyere p-piller
}

\author{
Selv om risikoen for blodpropp er lav, er det flere som blir rammet etter \\ bruk av p-piller som inneholder gestagenene drospirenon, desogestrel \\ og gestoden enn etter bruk av p-piller med levonorgestrel.
}

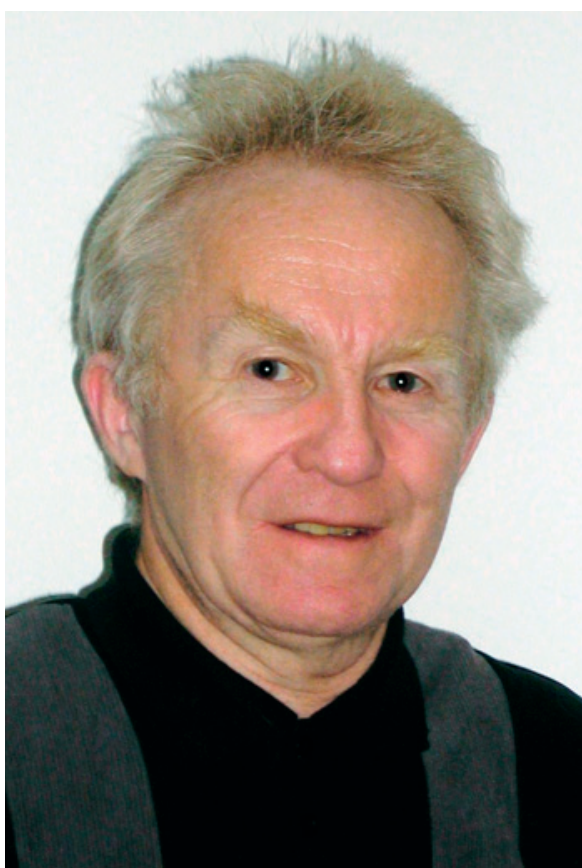

Finn Egil Skjeldestad, artikkelens fjerdeforfatter. Foto privat

Frem til midten av 1990-årene oppfattet man østrogenkomponenten som det farlige virkestoffet i p-pillene. Denne oppfatningen ble modifisert i 1995, da man fant at p-piller som inneholdt gestagenene desogestrel og gestoden fordoblet risikoen for blodpropp sammenliknet med p-piller som inneholdt gestagenet levonorgestrel. Tilsvarende skjedde kort tid etter at p-pillen med gestagenet drospirenon ble lansert i 2001.

I perioden 1995-2011 har 11 studier vist at det er en signifikant $ø$ kt risiko for blodpropp hos brukere av p-piller som inneholder desogestrel/gestoden, mens man i fire studier ikke fant noen forskjell når man sammenliknet disse brukerne med brukere av levonorgestrelpiller. Fire studier viste økt risiko for drospirenonbrukerne, mens det $\mathrm{i}$ to studier ikke var noen forskjell.

Etter at danske resultater ble publisert i $B M J$ i 2009 (1), oppfordret The European Medicine Agency forskergruppen til å reanalysere resultatene under supervisjon av en internasjonal styringsgruppe. Resultatene er nylig publisert i $B M J(2)$.

- Forskjellen i risiko for blodpropp mellom bruk av drospirenon-, desogestreleller gestodenholdige p-piller og bruk av levonorgestrelholdige p-piller var større ved denne reanalysen, sier professor Finn Egil Skjeldestad ved Universitetet i Tromsø, som er medforfatter på den nye danske studien. - I de siste analysene var det tatt hensyn til utvalgsskjevheter (left censoring bias) og bytte av p-pille med og uten pauser. Forskjellen mellom de nye og de levonorgestrelholdige p-pillenes evne til å fremkalle blodpropp ble større når bare validerte diagnoser inngikk i analysene.

Etter at artikkelen ble publisert på nett i $B M J$, er det kommet ytterligere en FDArapport og en israelsk studie som viser at drospirenonholdige p-piller oftere fremkaller blodpropp enn levonorgestrelholdige p-piller. Det er imidlertid ingen grunn til at kvinner som bruker p-piller med gestagenene drospirenon og desogestrel skal slutte med disse på grunnlag av de nye funnene. Men leger og helsesøstre som forskriver p-pillen til nye brukere, bør ha i mente at de nyere pillene gir høyere risiko for blodpropp enn de p-pillene som kom på markedet for noen tiår tilbake, sier Skjeldestad.

\section{Forskning på p-piller}

Professor Øjvind Lidegaard, Rikshospitalet, Universitetet i København, leder en gruppe som bruker registerdata fra flere danske helseregistre for å undersøke sammenhengen mellom eksponering av hormoner og blodpropp og kreft som endepunkter. Gruppen har publisert en rekke viktige artikler om bruk av p-piller og venøs og arteriell blodpropp, hormoner i overgangsalderen og brystkreft/eggstokkreft. Finn Egil Skjeldestad ved Institutt for klinisk medisin, Universitetet i Tromsø, er medforfatter på den seneste artikkelen, som ledd $i$ arbeidet fra den internasjonale styringsgruppen som ga råd til Øjvind Lidegaards prosjektgruppe.

\section{Erlend Hem}

erlend.hem@medisin.uio.no

Tidsskriftet

\section{Litteratur}

1. Lidegaard $\emptyset$, Løkkegaard $E$, Svendsen AL et al. Hormonal contraception and risk of venous thromboembolism: national follow-up study. BMJ 2009 339: b2890.

2. Lidegaard $\emptyset$. Nielsen LH, Skovlund CW et al. Risk of venous thromboembolism from use of oral contraceptives containing different progestogen and oestrogen doses: Danish cohort study, 2001-9. BMJ 2011; 343: d6423
Ordforklaringer

P-piller og lungeemboli: Før p-pillen ble innført på registreringsfritak i Norge (1963), var den første rapporten om lungeemboli og $\mathrm{p}$-piller publisert i The Lancet (1).

Left censoring bias: Hvis man ved studiestart tar hensyn til at deltakerne har vært eksponert tidligere og klassifiserer dem i henhold til hvor lenge de har vært eksponert (brukt p-piller før) har man tatt hensyn til «left censoring bias». Dersom man ikke tar hensyn til dette, blir eksponeringstiden feil.

\section{Litteratur}

1. Jordan WM. Pulmonary embolism. Lancet 1961; ii: $1146-7$.
Artikkelen ble e-publisert 25.10. 2011 i BMJ (www.bmj.com), som regnes som en av de «fem store» innen medisinsk publisering, ved siden av New England Journal of Medicine, JAMA, Annals of Internal Medicine og The Lancet.

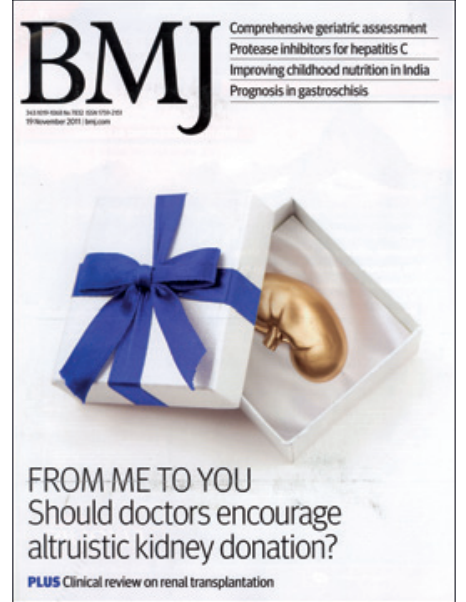

